\title{
Economic Assessment of Microfinance in Women Empowerment in Bangladesh and Some Unsolved Judgments
}

\author{
Farzana Yesmin Chowdhury \\ Assistant Professor, Department of Economics, Premier University, Chittagong, BANGLADESH \\ *E-mail for correspondence: farzanayesmin57@yahoo.com
}

https://doi.org/10.18034/abr.v7i3.17

\begin{abstract}
This article provides a quantitative outcome evaluation of microfinance in women empowerment in Bangladesh. It first evaluated the economic assessment of microfinance which showed the positive outcome of the economic indicators. At the same time, it also underlines some persisting unresolved methodical issues as well as economic issues. This analysis reflects the economic significance along with limitations of the microfinance program in Bangladesh since its beginning in the 1980s, and it will make comfortable for the further critical analysis of the contribution of the microfinance in women empowerment in Bangladesh.
\end{abstract}

Key words: Microfinance, poverty, women empowerment, entrepreneurial skills, endogeneity issues, selection bias

\section{INTRODUCTION}

Bangladesh has established herself as the pioneer in microfinance services since their inception in the early 1980s. Now Bangladesh is known as the most widespread microfinance service providing country in the world. Considering the socioeconomic and socio-cultural condition, Muhammad Yunus first developed microfinance as a non-profit model in 1976 at Grameen Bank $(\mathrm{GB})$ in Bangladesh. The neoliberal remaking of global governance and state-based policies are considered to date from 1980.

Neoliberalism as global governance is often identified with structural adjustment programs. However, it is indispensable to recognize that poverty remained the significant target of world development policy and the microfinance emerged as one of the most effective and flexible development tools under the neoliberal policy to fight against global poverty (Hickel 2014).

Its emergence is based on the judgment that poor people had been classified as 'unbankables'; could be converted as dependable bank clients (Cull et al. 2009). Microfinance programs offer small loans (especially poor women) to promote small-scale entrepreneurial activities (in the informal economy) without any physical collateral. These poor people are allowed to form a group to obtain access to loan as it is a group-based lending program and microfinance institutions (MFIs) traditionally charged highinterest rates (Morduch 1998; Fernando 200; Imai et al. 2012).
In this context, members of a microcredit group acted as mutual guarantors for each other. The MFIs strictly monitor the borrowers' behavior to ensure weekly and fortnightly loan repayment and punctuality (Morduch 1998; Uddin 2014). They have however, had great success in delivering financial services to poor women at a very low default rate. The transaction costs for lenders of maintaining the credit discipline among these poor borrowers are very high. MFIs maintain credit discipline through group pressure and monitoring borrower's behavior (Khandker \& Pitt 2003; Yaron 1994; Morduch 1998). The objectives of the group based approach include encouraging savings, improving income and thus improving the debt collection rate, and providing a platform to empower poor women (ibid).

According to Sen's (1999) analysis, microfinance provided a reliable platform for the poor females to access the capital market. This credit program connected the underprivileged segment of the society with economic activities which in turn created wealth and in the long run empowered women socially and financially. An extensive of studies has been accomplished on the economic effect of microfinance on women's empowerment because it has enchanted a number of development agencies and academics.

This article presents an impact assessment of the microfinance on women's empowerment through the prism of an economic perspective in Bangladesh. Simultaneously, it also underlines some persisting 
unresolved methodical issues as well as economic issues in the microfinance. In this regards, two key articles provided the starting point for this review- Khandker (2005) "Microfinance and poverty: using panel data from Bangladesh" and Khandker \& Samad (2014) "Dynamic Effects of Microcredit in Bangladesh."

Researchers have emerged with many interesting findings in microfinance evaluation; some studies argued that microfinance contributed to poverty altitude and women's empowerment (Hashemi et al.1996, Mahjabeen 2008; Khandker \& Samad 2014, Khandker 2005). Other researchers have reservations and have critiqued the claims of the positive impact of microfinance (Jahiruddin et al. 2011, Rahman 1999, Montgomery 1996). Some studies have illustrated the inability of microfinance to reach the poorest of the poor sections of the society (Scully 2004; Chowdhury \& Matin 2001; Amin et al. 2003). Among these researchers, most of the economic literature is based on econometric assumptions as limitations of econometric models and lack of accurate data problems could overcome through these assumptions.

It is also important to note from these economic literature failed to identify the various econometric problems like selection bias, endogeneity issues, and analysis of the broader economic effect.

On the other hand, World Bank and leading MFIs like GB, BRAC, ASA have written comprehensively on the positive claims of such studies. They have highlighted the microfinance model as the panacea to reduce poverty and empower women in Bangladesh, and globally rather than overcome the mentioned problems. The majority of the evaluation based economic literatures drew its statistical data from either World Bank, or the leading MFIs, which claim that microfinance programs had a favorable outcome on women's socio-economic status through income generation and education. The research literature on microfinance also demonstrates that it has ensured the distribution of capital flows to the marginalized people. Yet, there is no national consensus conducted in Bangladesh which strongly supports all these claims in the above-mentioned literature.

To analyze the economic effect of microfinance program on women's empowerment, I will focus on the role and achievement of 2006 Nobel Peace Prize winner, the GB alongside two other leading MFIs, BRAC (Bangladesh Rural Advancement Committee) and ASA (Association for Social Advancement) in Bangladesh.

\section{PeRsPeCtive Of Economic ImPACt Assessment OF Microfinance Based on Selected Impact Studies}

This section assesses the economic effect of microfinance on the poor people in Bangladesh. It also point-out some unresolved economic critical issues that are raised by microfinance activities. The most widespread impact studies of microfinance, Khandker (2005) and Khandker \& Samad (2014) have found sound evidence that microfinance programs helped poor women to increase income, consumption and reduce poverty in Bangladesh. In these studies, the data have derived from a long panel survey over 20 years (panel data tracks multiple variables over time for the identical individuals and also be referred to as longitudinal data).

Considering the range, exposure, impact outcome set and broad and quality of methodology used, these economic studies are often regarded as 'mother of all surveys in microfinance' (Khalily 2004, p.337). It is the first key study that Khandker \& Samad (2014) investigated various dimensions of microcredit effects on a set of behaviors which confirmed earlier results of Khandker (2005).

Khandker (2005) and Khandker \& Samad's literature (2014) used panel household survey data which have accomplished at three points (1991/92,1998/99 and 2010/11) over 20 years in 87 villages in 29 thana ( 24 thana have selected as program areas and 5 thana as non-program control) of rural Bangladesh. A set of wide-ranging questionnaires have designed for data collection. For the data analysis, a variety of econometric techniques have used.

For instance, the maximum-likelihood method was applied to determine both loan demand and the effect of microfinance. Three villages from each thana were selected randomly. At the household level, the parameters taken into consideration are consumption, savings, income, education, and asset accumulation. At the individual level, the core indicator was woman empowerment. At the aggregate level, the village level of outcome factors were wages and employment.

Outreach, cost efficiency, and sustainability have considered as the institutional outcome parameters. These outcomes have obtained with cross-sectional data or short panel data. Khandker \& Samad (2014) investigated various dimensions of microcredit effects on a set of behaviors which confirmed earlier results of Khandker (2005).

According to these groundbreaking studies, MFIs have made massive strides in providing financial services to poor women. Khandker (2005) assessed that the poverty rate had reduced by $20 \%$ during the survey period (between 1991/92 and 1998/99) and that microfinance contributed to half of this reduction. Further, with the extension of the survey, Khandker \& Samad (2014), from $1991 / 92$ to $2010 / 11$, household income has raised by more than double among the microfinance borrowers (Table1). In the same period, other economic indicators increased considerably which are elucidated as follows:

\section{The effect of microfinance on income}

In general, microfinance borrowers used to loan money for self-employment activities (ibid). During the 1980s, the early years of microfinance operation, the traditional sector including fisheries and poultry considered as the 
immense part of self-employment activities of the poor women. Later this extended to agriculture, food processing, and transport, housing, and livestock sectors in the rural areas (BIDS 2001; Ahmed 2009).

There was also a change in trade patterns over this period an earlier predominance of small-scale trade turned into medium and large-scale trade in the later years (ibid). So there are various factors like increase in self-employment as well increase in wages which contributed to increase in income. Khandker \& Samad (2014) argued that self-employment activities led to shrinkage in labor supply in the rural economy which may have assisted to amplified income.

Access to capital market gives the confidence to the borrowers. Consequently wage and self-employment are higher in non-agricultural sector (Ahmed 2009, Khandker \& Samad 2014).Wider participation in self-employment (especially for women) in off-farm economic activities increased significantly in rural society (Rahman 2000; Khalily 2004; Pitt et al. 2003). The MF borrowers were also able to ensure employment on their personal ranches because of their enhanced access to the land leasing market.

Based on Khandker (1998a) investigations, between 1991/92 and1998/99, average household income increased for the women by around 30\% for GB and 33\% for BRAC members (Khalily 2004, p.337; Develtere \& Huybrechts 2005).

\section{The effect of microfinance on consumption}

Microfinance contributed to income growth which in turn enhanced consumption. Over the period, Khandker (2005, p.266) argued that the marginal propensity of female borrowers to use loans for consumption was higher than that of male borrowers.

It was estimated to be roughly $18 \%$ for women borrowers and $11 \%$ for the male borrowers. In part, this is because MFIs lent money to poor women exclusively. Besides, by and large, women are liable for nourishing their children and incurring health and education costs. Khandker's (2005) findings also supported the above-mentioned claim that microfinance program of GB, ASA, BRAC and other MFIs promoted human development through education as well as raised awareness on health issues like safe water, sanitation, family planning among the poor borrowers (ibid).

\section{Effect of microfinance on poverty reduction}

Between the periods 1991/92 to 1998/99, there was a significant decline in extreme poverty (households with 0.2 acre or less land cited in Khandker \&Samad (2014) and moderate poverty (households with more than 0.49 acre land (ibid)). Sen (1999) also held the identical view that microfinance reduced poverty in Bangladesh. For instance, microfinance reduced moderate poverty by $1.6 \%$ points a year among the participants (Table1).The extent of poverty abatement was more pronounced among the borrowers than non-borrowers of the microfinance program (Table1).

Khandker (2005) claimed that poverty rate reduced by $20 \%$ throughout the period and microfinance contributed to half of the reduction. There was also a large-scale devastating flood in 1998, which mainly affected the poor households. So, such a poverty reduction level is quite significant taking into account this natural disaster.

Table 1: Household level outcome indicators by micro credit participation status: 1991-2011

\begin{tabular}{|c|c|c|c|c|c|c|}
\hline \multirow{2}{*}{ Outcomes } & $1991 / 1992$ & \multicolumn{2}{|c|}{$1998 / 99$} & \multicolumn{2}{|c|}{2011} \\
\cline { 2 - 7 } & $\begin{array}{c}\text { Participants } \\
(\mathrm{N}=769)\end{array}$ & $\begin{array}{c}\text { Non-Participants } \\
(\mathrm{N}=483)\end{array}$ & $\begin{array}{c}\text { Participants } \\
(\mathrm{N}=1,014)\end{array}$ & $\begin{array}{c}\text { Non-Participants } \\
(\mathrm{N}=420)\end{array}$ & $\begin{array}{c}\text { Participants } \\
(\mathrm{N}=1,554)\end{array}$ & $\begin{array}{c}\text { Non-Participants } \\
(\mathrm{N}=334)\end{array}$ \\
\hline $\begin{array}{c}\text { Per Capita Income } \\
\text { (Tk/month) }\end{array}$ & 521.8 & 495.6 & 502.7 & 523.1 & 1066.0 & 114.3 \\
\hline $\begin{array}{c}\text { Per Capita } \\
\text { Expenditure }\end{array}$ & 327.3 & 318.6 & 440.0 & 436.9 & 571.6 & 604.0 \\
\hline Moderate poverty (\%) & 86.3 & 87.6 & 60.6 & 58.2 & 32.9 & 34.6 \\
\hline Extreme Poverty (\%) & 75.1 & 78.5 & 43.6 & 46.5 & 16.2 & 23.1 \\
\hline $\begin{array}{c}\text { Male labour supply } \\
\text { (hours/month) }\end{array}$ & 195.4 & 189.5 & 227.8 & 206.0 & 200.9 & 131.4 \\
\hline $\begin{array}{c}\text { Female labour supply } \\
\text { (hours/months) (\%) }\end{array}$ & 38.8 & 37.2 & 30.1 & 20.1 & 56.2 & 39.6 \\
\hline $\begin{array}{c}\text { Non-land asset } \\
\text { value (Tk) }\end{array}$ & $18,273.0$ & $12,830.7$ & $20,089.2$ & $25,415.2$ & $62,595.9$ & $68,294.3$ \\
\hline Net worth (Tk) & $68,400.2$ & $35,953.3$ & $113,613.3$ & $144,981.7$ & $287,625.0$ & $269,349.1$ \\
\hline
\end{tabular}

Source: WB-BIDS surveys 1991/92 and 1998/99, and WB-InM survey 2010/11 (Khandker \& Samad 2014).

Effect of microfinance on human development

MFIs also led to human capital development. For instance, one of the major positive outcomes was the accelerating number of school enrolment of children. Khandker \& Samad (2014) showed that education had experienced steady growth over the period of the survey (53\% in 1991 to $70.4 \%$ in 2011). Khandker (1998a) asserted that one percent increase in microfinance credit for female borrowers increased the probability of school enrollment by $1.9 \%$ for girls and $2.4 \%$ for boys. 


\section{Effect of microfinance on saving and asset accumulation}

Access to capital market significantly boosted savings and asset accumulation among the borrowers. Current savings and net worth of asset are higher among the microfinance borrowers than non-borrowers (ibid) (Table1). An impact assessment of ASA borrowers indicated that the average value of physical assets increased by $127 \%$ in rural areas and about $150 \%$ in urban areas over a five years (20052010) period (Rahman et al. 2012).

After more than two decades of active presence, microfinance has carved itself towards a mature sector in Bangladesh. Microfinance has transformed itself rapidly from a geographic niche lending product to a globally recognized form of finance and became more refined and diverse.

The effects of microfinance, using long-panel data over the three survey period (Khandker 2005; Khandker \& Samad 2014) demonstrated that group-based loan programs had far-reaching effects in improving household welfare. Despite differences in methodology, impact assessments in the economic literature showed that overall microfinance helped the poor to overcome poverty.

Overall, an economic assessment of microfinance in Bangladesh indicates the significant improvement in the welfare of poor rural women. But simultaneously, all of these economic literatures have some unresolved issues which will be discussed in the next section.

\section{Common Findings in Economic Assessment of}

\section{MiCROFINANCE BUT SOME UNRESOLVED CRITICAL ISSUES}

In the microfinance context, all the economic literatures have adopted different methodologies with diverse arguments. The Quasi-experimental design was implemented in each of these reviewed studies. Primarily, a quasi-experiment is not a true experiment because it does not have randomly assigned groups.

Quasi-experimental research shares likenesses with the traditional experimental design or randomized controlled trial, but they specifically lack the element of random assignment to treatment or control (Gujarati 2009, p.624). In the Khandker's (2005) literature, quasi-experimental design (treatment group and control group) was used to estimate the effect of microfinance.

Further, most of the microfinance studies are based on economic assumptions and econometric techniques. These econometric practices created various difficulties such as endogeneity issues and selection bias. endogeneity means in the regression model if one or more endogenous variables (independent variables) are correlated with the error term. In this case, estimate the regression coefficient by using the Ordinary Least Square (OLS) method then obtain unbiased estimators (Gujarati 2009, p.446).
Or Fixed effects (FE) method was used to deal with endogeneity. This method is used to determine impact outcomes (consumption, expenditure) which make the estimates unbiased and efficient. FE method is a kind of statistical method which represents the observed quantities in terms of explanatory variables and treated as if the quantities are non-random (ibid, p.627).

Selection bias is a source of biasness in the research sampling. The selection bias may lead to an inaccurate conclusion in the study, if it is not identified. That means, if an experiment only selects people of a certain event with similar characteristics and excludes any group that deviates from these factors (ibid), it causes selection bias. Therefore, all these problems can overcome through using precise econometric techniques.

In Khandker's (2005) study, selection bias issue has resolved with the use of panel data as well as the endogeneity issue has mitigated through the efficient use of econometric techniques. For instance, the fixed method was used to resolve both household and village level endogeneity and selection bias problem. FE methods used to determine impact outcomes (consumption, expenditure) which make the estimates unbiased and efficient.

For example, unobserved household income which might be a condition of the credit demand may increase momentarily, so households may be willing to acquire more loans. It is also applicable to the individual's decision to participate or not to participate in microfinance program. Though, an individual's participation decision determined by MFIs observation such as individual characteristics, family income, asset, etc., but these observations may differ from individual to individual.

However, Rahman (2001) (Rahman (2001) commented on Khandker's (1998) article. But all of Khandker's works are an ongoing process. Both the article, Khandker 2005; Khandker \& Samad 2014) multiple times cited in Khandker (1998) article) criticized that Khandker's (2005) methodology is somewhat complex, and difficult to comprehend as the basic supposition of the FE method which means over the time, the unobserved characteristics remain fixed, but these characteristics may change for different reasons.

Moreover, program participation may also influenced by some unobservable characteristics. Khandker (2005) controlled all these endogeneity issues through the social, economic and political factors in assessing program (Khalily 2004). Moreover, the survey's (Khandker 2005; Khandker \& Samad 2014) findings have debated due to restrictive econometric assumptions for model identification of program benefits (Roodman \& Morduch 2009).

Nevertheless, the critical literatures of the econometric, descriptive and case studies carried out in Bangladesh on the impact assessment of microfinance are quite consistent regarding direction of impact. In this context, authors 
used data and arranged description outline according to their arguments. Consequently, the results of the descriptive and case studies are consistent when they are derived from the econometric studies as well.

In this case, Khandker's (2005) result is quite expected due to precise econometric techniques are used in the whole literature. Different authors assessed the impact of microfinance from different discipline under varying assumptions. Under diverse methodologies, if the drawbacks of these literatures are considered, then it provided ambiguous results about the impact of microfinance on women empowerment.

Further, most of the economic literatures on the 'effect of microfinance in Bangladesh' that I have reviewed for my analysis have common findings. However, methodologies followed in different studies are not essentially consistent and unique. Therefore, the economic literatures seem both unified in its agreement that microcredit alleviated poverty, but on a closer examination it unveils a range of economic problems which are discussed in details below. For example, no economic literature conducted a comparative analysis of the effect of microfinance between borrowers and non-borrowers of the microfinance credit program.

Without this comparison, it is difficult to understand the strength of microloan program among the poor people. For the quasi-experimental design, Rahman (1998) argued that it could be less effective without such comparative analysis to assess the effect of microfinance in Bangladesh.

Interestingly, all these economic literatures have not come up with proper explanations about the matters or sometimes overlooked these economic assessment problems. For instance, both the analysis (Khandker 2005; Khandker \& Samad 2014) in the year 2010/11, there were inconsistent patterns in per capita income and expenditure between borrowers and non-borrowers from microfinance program. Non-borrowers per capita income and expenditure were higher than microfinance borrowers (Table1). Further, it seems that poverty has dropped significantly in last 20 years for both microfinance borrowers and non-borrowers. For instance, extreme poverty declined by $2.9 \%$ points per year for microfinance borrowers, compared to a yearly reduction of $2.8 \%$ points for the non-borrowers (Khandker \& Samad 2014), though difference between two categories is insignificant (0.1).

This minor variance raises the question if non-borrowers have the greater income than microfinance borrowers then what is the impact of microfinance on the economy? In considering this question, it is important to know that Bangladesh experienced significant economic growth due to the enlargement of the manufacturing sector, in particular, readymade garments (Bhattacharya et al. 2002).
The contribution of RMG sector has particular significance for any economic assessment of the microfinance because $80 \%$ of RMG workers are rural women. Agricultural production has also experienced an upward trend, and some agricultural based industries were established in the rural areas (Haggblade et al. 2007). Nowadays many poor women opted for better income opportunities rather than getting them chained to a high interest based microfinance program.

Another issue in assessing the effect of microfinance is that both Khandker (2005) and Khandker \& Samad (2014) argued that to ensure the success of microfinance programs, borrowers need entrepreneurial skills along with an active market. They also drew attention to product diversification in microfinance due to low demand for the product.

It is claimed that microfinance has had the effects on poverty levels but who provided entrepreneurial support to these poor and illiterate women? And who has ensured the effective local market for this informal economy? The policy question remains that who will do this in the future?

Another difficulty with the evaluation of the claims made for the economic assessment of microfinance is that the literatures have never distinguished the effects of informal (local money lenders), formal (commercial bank) and microfinance at the household level. Yet, no major studies conducted on the economic effect of microfinance in Bangladesh which have addressed this issue even though more than one-third of the microfinance borrowers obtained loans from the informal market, and about onesixth borrowed from the formal credit market (Khalily et al. 2000; Zohir et al. 2001).

For example, the outcomes of (Khandker 2005; Khandker \& Samad 2014) showed that microfinance has had a positive effect on income and consumption expenditure among their borrowers. It is not clear whether this it was due to borrowing from informal sources or formal sources or from the rise in income because of microfinance intervention (Khalily 2004). In the same context, microfinance is not the only an anti-poverty strategy in Bangladesh. There are other cash transfer programs of the government like food-for-work program and small loan programs of the formal banks. All of these strategies have contributed to poverty reduction. However, none of the economic literature has separated out the effects of these different sources of income and credit.

Moreover, the number of microfinance debtors has significantly increased over the last two decades - from $26.3 \%$ in $1991 / 92$ to $48.6 \%$ in $1998 / 99$ and $68.5 \%$ in 2010/11(Khandker \& Samad 2014, p.5).

Multiple memberships in the numerous programs are the major contributor to the increase in the number of MFIs debtors. This trend barely existed in the early 1990s. In the 
third survey phase (2010/11), Khandker \& Samad (2014) showed that almost $61 \%$ GB members were also members of other MFIs. In general, 31.9\% households in rural Bangladesh were members of multiple microfinance programs in 2010/11, which increased from $8.9 \%$ in 1998/99. What are the explanations for such an increase in multiple memberships? Over this period the number of MFIs has also increased which has smooth the way for multiple memberships of MFIs.

It is mentionable that there were some 698 registered MFIs in June 2013, compared with only a few in 1991/92 (MRA 2014), Khandker (2005) which supports the abovementioned statement. All these MFIs served 25 million borrowers with about total outstanding loans of USD3.3 billion and total deposits of USD1.2 billion in the year 2013 (MRA 2014) compared to USD1.5 billion outstanding loan balance in 2008 (Khandker \& Samad 2014). It is evident from the recent economic literatures that too much credit or too many MFIs may be neither good for borrowers nor good for the economy (Khalily 2004).

On the other side, usually the products that are made from microfinance loans have limited demand and hence a small market. In this situation, availability of easy loan in the economy - poor people cannot use loan money in more productive ways to expand their businesses and get trapped into vicious debt cycles (ibid). As a result, these borrowers fail to ensure fair prices for their produces which severely impacts on their livelihood as well as loan commitments. On the other, excessive unproductive loan increases inflation in the economy. Overall, all these factors adversely affect the whole economy. With rising competition among MFIs with a partial diversification of product design and market, poor household's continuous borrowing may create conditions for market saturation and disorder. Consequently, it generates diseconomies in the rural economy.

To some extent, MFIs are ensuring capital access to the poor but it does not provide other requirements for the borrowers and also fails to make available new market for the existing borrowers. Hence, microfinance progress may generate micro-debt dependences (Khandker \& Samad 2014), where borrowers who have the possibility to borrow from multiple sources are possible to be overindebted or trapped in poverty.

This issue raises questions, not only about the past economic assessment of microfinance but whether is it the best policy focus for the future? Borrowers may also borrow from multiple MFIs as a strategy of risk prevention (Chaudhury \& Matin 2002). In this context, sometimes, a lack of financial literacy compromises the capability of the poor borrowers to understand the risks and benefits of credit, borrowers may have failed to work within a peer group or sometimes money is needed for unwanted emergencies (illness, natural disaster) (Evans et al. 1999).
All these factors may potentially create an unsustainable loan repayment condition for the borrowers. Or we can say that poor borrowers using multiple memberships of MFIs to repay their loan repayment are just like credit cards of the commercial bank which involve frequent transactions of money (Rosenberg et al. 2009).

It is also apparent that the rising of multiple program membership has not yet caused any impact on loan recoveries of MFIs (Khandker \& Samad 2014). Due to such strict loan repayment policies and high-interest rates, poor borrowers often pay the outstanding loan from one MFI by borrowing money from another.

Moreover, expanding number of MFIs indicate the commercialization of microfinance where MFIs are only providing money to the poor subject to enforcement of timely loan repayment in any way available (Rahman 2000). So, multiple membership of MFIs issue is a far cry from the concept of poverty reduction and women's empowerment which presents an ethical dilemma.

Despite the overwhelming success of MFIs in reaching to the poorest of the poor, the accumulated benefit of microfinance (measured in terms of income and consumption and other dimensions of economic welfare) is still a debatable issue. In contributions to this debate, Amin et al. (2003) and Dutta (2004) have argued that there is mixed evidence as to whether microfinance benefited the poor or not because there is significant evidence that it failed to outreach the extremely poor.

There is increasing subjective confirmation that the poorest $20 \%$ of the total population of the society, excluded from microfinance programs (Hulme \& Mosely 1996). All these people are economically active, with a potential to obtain microfinance but are not covered by the MFIs. Now the question is why this group of extremely poor people excluded from the microfinance program? MFI's decisions determine the entrance and access of these people to microfinance and not the borrowers' own intentions.

Such decisions may depend on visible and invisible features of the family and the individuals including financial wealth. Generally, these attributes differ from individual to individual. These unobservable characteristics nevertheless determine microfinance program participation. According to the microfinance model, women who are landless and impoverished wage laborers constitute the target groups.

The evidence demonstrates that the way these criteria applied may successfully identify the poor, but still not ensure equal opportunity of access for these poor people to microfinance. All these characteristics based on social class, literacy, loan repayment capacity, health status and other socio-cultural customs and practices which effect group decisions about member selection and creditreadiness in microfinance programs of the MFIs (Pitt \& 
Khandker 1996; Hulme \& Mosely 1996, Evans et al. 1999). All these factors potentially create biased access to the poor borrowers.

Further, there is a concern, which a new trend toward minimalist microfinance (i.e., providing no services beyond credit) which may worsen these exclusionary trends (Evans et al. 1999). This new trend microfinance argument is also supported by the increasing number of MFIs and the number of multiple borrowers of the MFIs. Finally, institutional incentives of the MFIs may impose both a program related barrier and a client-related barrier to participation. Overall it sharpened towards serving a small part of poor people's financial need but does not reach the poorest people of Bangladesh.

\section{Conclusion}

From the overview of economic assessment of microfinance, it is clear that microfinance alone is not a viable tool to ensure women's empowerment in Bangladesh.

The economic literature has strong empirical and methodological foundation. The key studies by Khandker (2005) and Khandker \& Samad (2014) are long panel studies employing widely used econometric techniques and assumptions to deal with issues of endogeneity, selection bias and then obtained unbiased estimators. These key economic studies showed that MFIs had a positive impact on income and consumption, expenditure, reduction in poverty, net worth and asset accumulation, increase in women's self-esteem and social mobility. Empirically these studies support the widely held notion that MFIs managed and function profitably and with high scale of cost efficiency. Moreover, the users of these microfinance impact studies are the World Bank, leading MFIs, International agencies, and professionals, so the positive findings have a big influence on current objectives regarding women's empowerment and development in Bangladesh (Hulme 2000).

However, these economic studies do have some serious problems. All the cited literature including Khandker (2005) and Khandker \& Samad (2014) overlooked a number of critical issues or failed to resolve the question of microfinance impact on women's empowerment.

Among them, one of the most debatable issue is multiple memberships which created debt dependence among the borrowers. The authors have not explained the reasons for the multiple memberships of the MFIs (Khandker \& Samad 2014)

Rather they asserted that multiple memberships have no impact on the repayment rate, so MFIs are judged more on their profit performance than the issue of women's empowerment. MFIs programs also present barriers to the participation of the extreme poor in loan programs. Studies have shown that $20 \%$ of the poor are unable to obtain microfinance, hence there is a moral question- if microfinance program's policy objective is to reach the poorest of the poor women, then the vulnerable poor are unable to obtain loan, so how can microfinance justify the ethical and moral claim to be empowering poor women?

While the economic studies of the impact of microfinance have been extensive, they have not compared the effects of microfinance on borrowers and non-borrowers. Without such comparison, it is difficult to make conclusions about the specific impact of microfinance on empowering women in Bangladesh. Furthermore, while a large number of impact studies have conducted in Bangladesh but none have highlighted the basic problem of the borrowers - entrepreneurial and financial skills that are needed to utilize the loan money efficiently.

The positive claims about the microfinance are based on the quantitative indicators such as the number of borrowers, loan repayment rates. Outcomes measured by these indicators failed to reveal the institutional processes through which such outcomes have achieved. Therefore, a close inspection of the factors that prevent the poorest from being beneficiaries of microfinance is both timely and critical.

\section{REFERENCES}

Ahmed, S 2009, 'Microfinance institutions in Bangladesh: achievements and challenge', Managerial Finance, Vol. 35, no.12 pp. $999-1010$.

Amin, S, Rai, A.S \& Topa, G 2003, 'Does microcredit reach the poor and vulnerable? Evidence from northern Bangladesh', Journal of Development Economics, vol.70, no.1, pp.59-82.

Bangladesh Institute of Development Studies (BIDS) 2001, Final Report on BIDS Study on PKSF's Monitoring and Evaluation System (MES), October, Dhaka.

Bhattacharya, D, Rahman, M \& Raihan, A 2002. Contribution of the RMG Sector to the Bangladesh Economy. CPD Occasional Paper Series, vol. 50. no. 6.

Chaudhury, I. A \& Matin, I 2002, 'Dimensions and dynamics of microfinance membership overlap - a micro study from Bangladesh', Small Enterprise Development, Vol. 13, no.2, pp.4655.

Cull, R, Demirguc-Kent, A \& Morduch, J 2009, 'Microfinance meets the market'. Journal of Economic Perspectives, vol.23, no.1, pp. 167-92.

Develtere, P \& Huybrechts, A 2005, 'The impact of microcredit on the poor in Bangladesh', Alternatives: Global, Local, Political, vol.30, no. 2, pp.165-189.

Evans, T, G, Adams, A, M, Mohammed, R \& Norris, A, H 1999 , 'Demystifying nonparticipation in microcredit: a populationbased analysis', World Development, vol.27, no. 2, pp. 419-430.

Fernando, J, L 2004, Microfinance: Perils and prospects, Routledge, London.

Gujarati, D, N 2009, Basic econometrics. Tata McGraw-Hill Education.

Haggblade, S, Hazell, P, B \& Dorosh, P, A 2007, 'Sectoral growth linkages between agriculture and the rural nonfarm economy' Transforming the rural nonfarm economy: Opportunities and threats in the developing world, pp.141-182. 
Hashemi, S, M, Schuler, S, R \& Riley, A, P 1996, 'Rural credit programs and women's empowerment in Bangladesh', World Development, vol. 24, no. 4, pp. 635-653.

Hickel, J 2014, 'The 'girl effect': liberalism, empowerment and the contradictions of development', Third World Quarterly, vol. 35 , no. 8 .

Hulme, D \& Mosley, P 1996, Finance against poverty. Routledge, London.

Hulme, D 2000, 'Impact assessment methodologies for microfinance: theory, experience and better practice', World Development, vol. 28, no. 1, pp. 79-98.

Imai, K, S \& Azam, M, S 2012, ‘Does microfinance reduce poverty in Bangladesh? New evidence from household panel data', Journal of Development Studies, vol. 4, no.8/5, pp.633-653.

Jahiruddin, ATM, Short, P, Dressler, W \& Khan Adil, M 2011, 'Can microcredit worsen poverty? Cases of exacerbated poverty in Bangladesh', Development in Practice, vol. 2, no.8, pp. 1109-1121.

Khalily B, Imam M, O \& Khan S, A 2000, 'Efficiency and sustainability of formal and quasi formal microfinance programs in Bangladesh', The Bangladesh Development Studies, vol. 26, pp.103-146.

Khalily, M, A 2004, 'Quantitative approach to impact analysis of microfinance program in Bangladesh-what have we learned?', Journal of International Development, vol.16, no.3, pp.331-353.

Khandker, S, R \& Pitt, M.M 2003, 'The impact of group-based credit on poor household: An analysis of Pannel data from Bangladesh', World Bank, Washington, D.C.

Khandker, S, R \& Samad, H, A 2014, 'Dynamic effects of microcredit in Bangladesh', World Bank Policy Research Working Paper 6821.

Khandker, S, R 2005. 'Microfinance and poverty: Evidence using panel data from Bangladesh', The World Bank Economic Review, vol. 19, no. 2, pp. 263-286.

Mahjabeen, R 2008, 'Microfinancing in Bangladesh: Impact on households, consumption and welfare', Journal of Policy Modeling, vol. 30, no.6, pp. 1083-1092.

Microcredit Regulatory Authority (MRA) of Bangladesh, Microcapital Brief, August 1, 2014. www.microcapital.org/microcapital-brief-microcredit-regulatoryauthority.

Montgomery, R 1996, 'Disciplining or protecting the poor? Avoiding the social costs of peer pressure in micro-credit schemes', Journal of International Development, vol.8, no. 2, pp.289 305.

Morduch, J 1998, 'Does microfinance really help the poor?: New evidence from flagship programs in Bangladesh', Research Program in Development Studies, Woodrow School of Public and International Affairs.
Pitt, M \& Khandker, S 1996, 'Household and Intra-household Impact of the Grameen Bank and Similar Targeted Credit Programs in Bangladesh', World Bank Discussion Papers, No.320. Washington, D.C.

Rahman R, I 1998, 'Impact assessment studies on microcredit - a review of methodologies and indicators', Bangladesh Institute of Development Studies.

Rahman, A 1999, 'Micro-credit initiatives for equitable and sustainable development: Who pays?', World development, vol. 27, no.1, pp. 67-82.

Rahman, A 2001, Women and microcredit in rural Bangladesh: An anthropological study of the rhetoric and realities of Grameen Bank lending, Westview Press, Boulder.

Rahman, M, W, Luo, J, Ahmed, S \& Xiaolin, W 2012, 'The Synthesis of Grameen Bank, BRAC and ASA Microfinance Approaches in Bangladesh', World Applied Sciences Journal, vol. 20, no. 7, pp. 1055-106.

Rahman, R, I 2000, Poverty alleviation and empowerment through microfinance: two decades of experience in Bangladesh (No. 20), Bangladesh Institute of Development Studies.

Rahman, S. M 2000, 'Commercialization of microfinance in Bangladesh perspective',Global Development Research Center, Osaka, Japan, http://wwww. gdrc. org/icm/country/bangla-001. html.

Rashid, M \& Townsend, R.M 1993, 'Targeting credit and insurance: Efficiency, mechanism design, and program evaluation'. The World Bank and the University of Chicago, draft.

Roodman, D \& Morduch, J 2009, 'The impact of microcredit on the poor in Bangladesh: Revisiting the evidence', Center for Global Development Working paper 174, Washington, DC.

Rosenberg, R, Gonzalez, A \& Narain, S 2009, 'The new moneylenders: are the poor being exploited by high microcredit interest rates?', Moving beyond storytelling: emerging research in microfinance (contemporary studies in economic and financial analysis, volume 92). Emerald Group Publishing Limited, Bingley, pp.145-181.

Scully, N 2004, 'Microcredit: No panacea for poor women', Global Development Research Centre, Washington, DC.

Sen, A 1999, Development as Freedom, Oxford: Oxford University Press.

Uddin, M.J 2014, 'Microcredit and building social capital in rural Bangladesh-drawing the uneasy link', Contemporary South Asia, vol.22, no.2, pp.143-156.

Yaron, J 1994, 'What makes rural finance institutions successful?', World Bank Research Observer, vol.9, no.1, pp. 49-70.

Zohir, S, Mahmud, S, Sen B, Asaduzzaman, M, Islam, J, Ahmed, N \& Mamun A, A 2001, Monitoring and evaluation of microfinance institutions, Bangladesh Institute of Development Studies, Dhaka. http://www. pksf-bd.org/bids_report. HTML.

$$
--0--
$$

Online Archive: https://abc.us.org/ojs/index.php/abr/issue/archive

\section{5) Worldcat Google scholar

